\title{
Autonomous underwater gliders monitoring variability at "choke points" in our ocean system: A case study in the Western Mediterranean Sea
}

\author{
Emma E. Heslop, ${ }^{1}$ Simón Ruiz, ${ }^{1}$ John Allen, ${ }^{2,3}$ José Luís López-Jurado, ${ }^{4}$ Lionel Renault, ${ }^{5}$ \\ and Joaquín Tintoré ${ }^{1,5}$
}

Received 31 August 2012; revised 25 September 2012; accepted 26 September 2012; published 31 October 2012.

[1] Recent data from an autonomous ocean glider in the Ibiza Channel (Western Mediterranean Sea) show variations in the transport volumes of water over timescales of daysweeks, as large as those previously only identifiable as seasonal or eddy driven. High frequency variation in transports of water masses has critical implications for ocean forecasting. Three potential modes of transport are proposed, which have the potential to simplify the previously observed complex pattern of flows. Restricted 'choke points' between ocean basins are critical locations to monitor water transport variability; the Ibiza Channel is one such 'choke point', where variation in the transports of water masses are known to affect the spawning grounds of commercially important fish stocks. Citation: Heslop, E. E., S. Ruiz, J. Allen, J. L. López-Jurado, L. Renault, and J. Tintoré (2012), Autonomous underwater gliders monitoring variability at "choke points" in our ocean system: A case study in the Western Mediterranean Sea, Geophys. Res. Lett., 39, L20604, doi:10.1029/2012GL053717.

\section{Introduction}

[2] Gliders are an emerging autonomous platform for oceanographic measurements [Rudnick et al., 2004; Testor et al., 2010]. The high-resolution data gained from gliders has already provided insight into the variability of major coastal currents [Castelao et al., 2008; Todd et al., 2011], the evolution of mesoscale eddy structures [Ruiz et al., 2009; Martin et al., 2009; Baird and Ridgway, 2012], mixing in the upper ocean and air-sea energy exchanges [Ruiz et al., 2012], and recently constituted an important part of the emergency response to the Deepwater Horizon oil spill.

[3] A complex interplay of oceanographic processes affects the circulation in this region of the Western Mediterranean Sea (Figure 1); a seasonal cycle is overlain by energetic mesoscale activity and modulated by the variable formation of deep and

\footnotetext{
${ }^{1}$ Marine Technologies, Operational Oceanography and Sustainability Department, IMEDEA (CSIC-UIB), Esporles, Spain.

${ }^{2}$ Ocean Biogeochemistry and Ecosystems, National Environmental Research Council, National Oceanography Centre, Southampton, UK.

${ }^{3}$ Now at School of Earth and Environmental Sciences, University of Portsmouth, Portsmouth, UK.

${ }^{4}$ Instituto Español de Oceanografia, Centro Oceanogràfico de Baleares, Palma de Mallorca, Spain.

${ }^{5}$ SCOCIB (Balearic Islands Coastal Ocean Observing and Forecast System), Palma de Mallorca, Spain.

Corresponding author: E. E. Heslop, IMEDEA (CSIC-UIB), c/ Miquel Marquès 21, E-07190 Esporles, Spain. (eheslop@imedea.uib-csic.es)

Published in 2012 by the American Geophysical Union.
}

intermediate water masses in winter. The effects of this interplay are concentrated in the Ibiza Channel, which with its narrow width and sill ( $80 \mathrm{~km}$ and $800 \mathrm{~m}$ at narrowest point), governs an important inter-basin exchange of water masses that is known to affect local ecosystems of global interest, specifically the abundance and distribution of Atlantic bluefin tuna larvae [Alemany et al., 2010].

[4] At the basin scale the Western Mediterranean has a cyclonic circulation involving Atlantic Water (AW) in the surface layer and Levantine Intermediate Water (LIW) in the layer below. On the western side of the Ibiza Channel the Northern Current (NC), part of the cyclonic circulation, flows south out of the Balearic Sea sub-basin, whilst on the eastern side, AW of more recent Atlantic origin (warmer and fresher) flows in from the Algerian sub-basin to the south. The AW inflows, which occur both through the Ibiza and to a lesser extent through the Mallorca channel, form the warm fresh core of the Balearic Current (BC) that flows northeast along the northwest coast of the Balearic Islands (Figure 1). This exchange has a seasonal cycle, with the range of transports for the NC determined as stronger in winter, $1.2-1.5 \mathrm{~Sv}$ $\left(1 \mathrm{~Sv}=10^{6} \mathrm{~m}^{3} \mathrm{~s}^{-1}\right)$, and weaker in summer, $0.5-0.3 \mathrm{~Sv}$ [Pinot et al., 2002]. In spring these flows can be interrupted by 'blocking' eddies which divert the NC (northeast) to follow and join the path of the $\mathrm{BC}$ along the northwest coast of the Balearic Islands, reducing the north/south exchange in the Ibiza Channel [Pinot et al., 2002; Pinot and Ganachaud, 1999]. The AW inflows have been observed to strengthen in late spring/early summer [Pinot et al., 2002].

[5] Eddies are a persistent feature in the seasonal cycle of the Balearic Sea forming within the sub-basin or further north, both cyclonic and anticyclonic 'blocking' eddies of variable size $(30-80 \mathrm{~km})$ have been observed in the Ibiza Channel. The anticyclonic 'blocking' eddies are frequently associated with cold cores of Western Mediterranean Intermediate Water (WIW) [Pinot et al., 2002; Pinot and Ganachaud, 1999], leading to the suggestion that this water mass plays a determining role in the Ibiza Channel transports. WIW is a cold winter produced water mass, generally identified as a temperature minimum layer below the surface AW [Salat and Font, 1987]. It is believed to form in the Gulf of Lion, Balearic and Ligurian Seas [Salat and Font, 1987; Conan and Millot, 1995; Vargas-Yáñez et al., 2012], during strong winter cooling events that cause a mixing and cooling of the surface AW to a buoyancy equilibrium between AW and LIW. An index to link winter atmospheric conditions in the Gulf of Lion (WIW production) to regional circulation scenarios has been proposed [Monserrat et al., 2008]. For the AW inflows, it has been suggested that they strengthen in response to the 


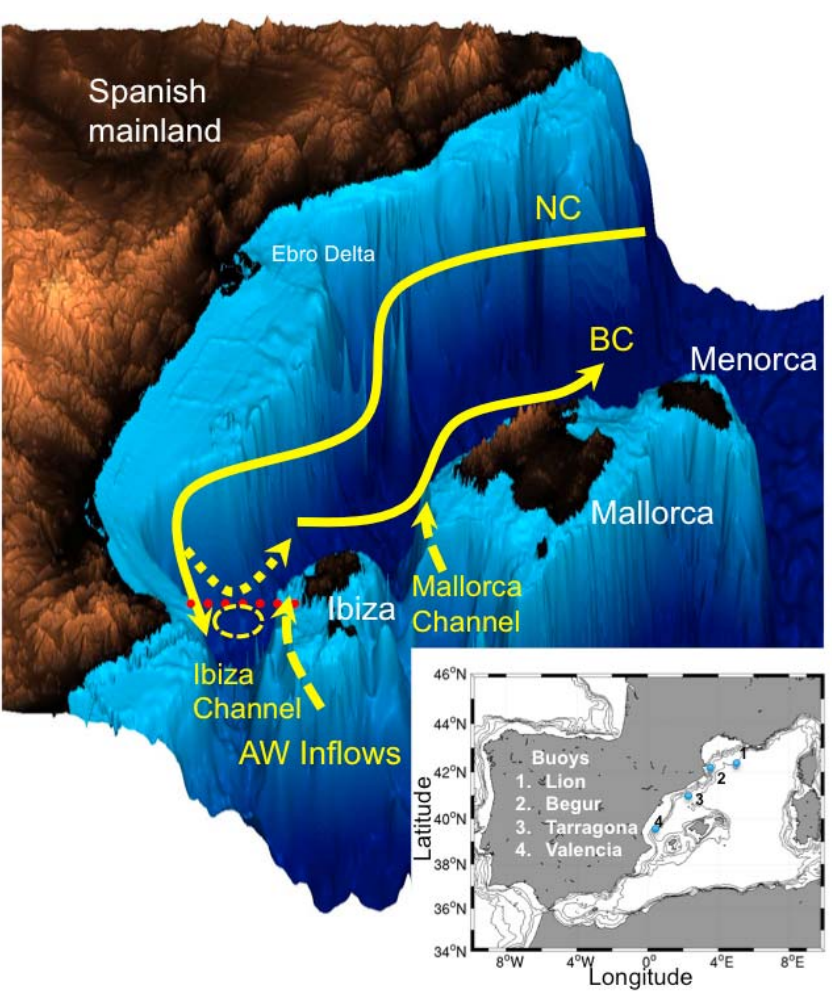

Figure 1. The Balearic Sea with main currents Northern Current (NC), Balearic Current (BC) and AW inflows through the Ibiza and Mallorca Channels. A 'blocking' eddy (yellow circle dashed line) and the re-circulation of the $\mathrm{NC}$ above the eddy (yellow dashed line) are also indicated. The approximate position of the glider transect is shown (red dots). (inset) Location of the Balearic Sea in the Western Mediterranean Sea, with oceanographic buoys (blue dots).

seasonal weakening of the $\mathrm{NC}$ and/or as a result of mesoscale activity to the south of the Balearic Islands [Pinot et al., 2002; Pinot and Ganachaud, 1999]. The strength, timing and location of AW inflows are known to influence the spawning grounds of migratory pelagic fish [Sabatés et al.; 2007, Alemany et al., 2010].

[6] As with other restricted "choke points" in the global ocean, for example Drake Passage in the Southern Ocean [Meredith et al., 2011] and the Fram and Denmark Straits in the North Atlantic, dynamic processes in the Ibiza Channel exert a controlling influence on the exchange of water volumes. It is important to monitor and characterize the variability of these exchanges [Send et al., 2010]. Previously most observations in the Ibiza Channel have been ship based, undertaken on a seasonal to annual basis and concentrated in the spring/summer months (Table 1). The most comprehensive of these surveys [Pinot et al., 2002] deployed moorings in the Ibiza and Mallorca Channels that monitored flows at a coarse spatial resolution. Gliders however can monitor variability on a days - weeks basis, at high spatial $(2 \mathrm{~km})$ resolution. To illustrate this we present the initial findings from a long-term glider monitoring program in the Ibiza Channel.

[7] The purpose of this study is to characterize the seasonal to sub-seasonal variability of the transport of water masses in the Ibiza Channel and so gain insight into the variety of dynamic processes occurring in this complex region. The article is organized as follows; Section 2 contains information on the datasets and methods; the results are presented in Section 3; a discussion regarding the impact of some key assumptions underlying the results in Section 4; Section 5 outlines the conclusions.

\section{Data and Methods}

[8] Five semi-continuous glider missions were undertaken in the Ibiza and Mallorca Channels between January and June 2011 (Table S1 in the auxiliary material), using a Slocum Deep Glider. ${ }^{1}$ Three to six transects of the Ibiza Channel were completed each mission, each transect $(80 \mathrm{~km})$ took an average of 3 days to complete, with 2 days for the deep (central) section of the channel (off the continental shelf with depths $\geq 200 \mathrm{~m}$ ) and used for the water volume transport calculations. Thus during a mission the deep channel was sampled every $2-3$ days. The glider performed a saw-tooth pattern through the water column between depths of $20 \mathrm{~m}$ and $950 \mathrm{~m}$, while navigating a standard transect line at $39^{\circ} \mathrm{N}$ (between surface waypoints at $38.99^{\circ} \mathrm{N}, 0.13^{\circ} \mathrm{E}$ and $38.98^{\circ} \mathrm{N}$, $1.10^{\circ} \mathrm{E}$ ), approximately perpendicular to the main currents (Figure 1). The maximum depth of the channel is approximately $950 \mathrm{~m}$ at this latitude. From January to June 2011 the glider performed 23 complete transects of the Ibiza Channel (Figure S1, auxiliary material). The average distance of the glider track from the transect line of was $1.8 \mathrm{~km}$ and the distance between CTD profiles approximately $2 \mathrm{~km}$ in the deep channel, $300 \mathrm{~m}$ on the shelf.

\footnotetext{
${ }^{1}$ Auxiliary materials are available in the HTML. doi:10.1029 $2012 \mathrm{gl053717.}$
}

Table 1. Transport Estimates in the Ibiza Channel

\begin{tabular}{|c|c|c|c|c|c|}
\hline \multirow[b]{2}{*}{ Reference } & \multirow[b]{2}{*}{ Survey } & \multicolumn{2}{|c|}{ Winter Transports (Sv) } & \multicolumn{2}{|c|}{$\begin{array}{c}\text { Summer } \\
\text { Transports (Sv) }\end{array}$} \\
\hline & & South & North & South & North \\
\hline Castellon et al. $[1990]^{\mathrm{a}}$ & Survey vessel May and Jun 1989 & & & 0.24 & \\
\hline López-Jurado and del Rio [1994] & $\begin{array}{l}\text { Survey vessel Nov 1990/Mar } 1991 \\
\text { Average } 6 \text { transects }\end{array}$ & $0.65 / 0.56$ & $1.08 / 0.51$ & & \\
\hline Pinot et al. $[1995]^{\mathrm{a}}$ & Survey vessel May and Jun 1991 & & & 0.2 & 0.5 \\
\hline Pinot and Ganachaud [1999] & Survey vessel Jun 1993 & & & 0.55 & 0.55 \\
\hline Pinot et al. $[2002]^{\mathrm{b}}$ & $\begin{array}{l}\text { Survey vessel Mar } 1996 \text { to Jun } 1998 \\
\text { Mean of winter/summer missions }\end{array}$ & 1.3 & 0.2 & 0.6 & 0.5 \\
\hline Ibiza Channel glider missions $^{\mathrm{a}}$ & $\begin{array}{l}\text { Ibiza Channel glider missions Jan } 2011 \text { to Jun } 2011 \\
\text { Mean of winter/summer transects }\end{array}$ & 1.0 & 0.4 & 1.0 & 0.3 \\
\hline
\end{tabular}

\footnotetext{
${ }^{\mathrm{a}}$ Transports estimated using a level of zero velocity assumption
}

${ }^{\mathrm{b}}$ Transports estimated using an inverse box model method. 

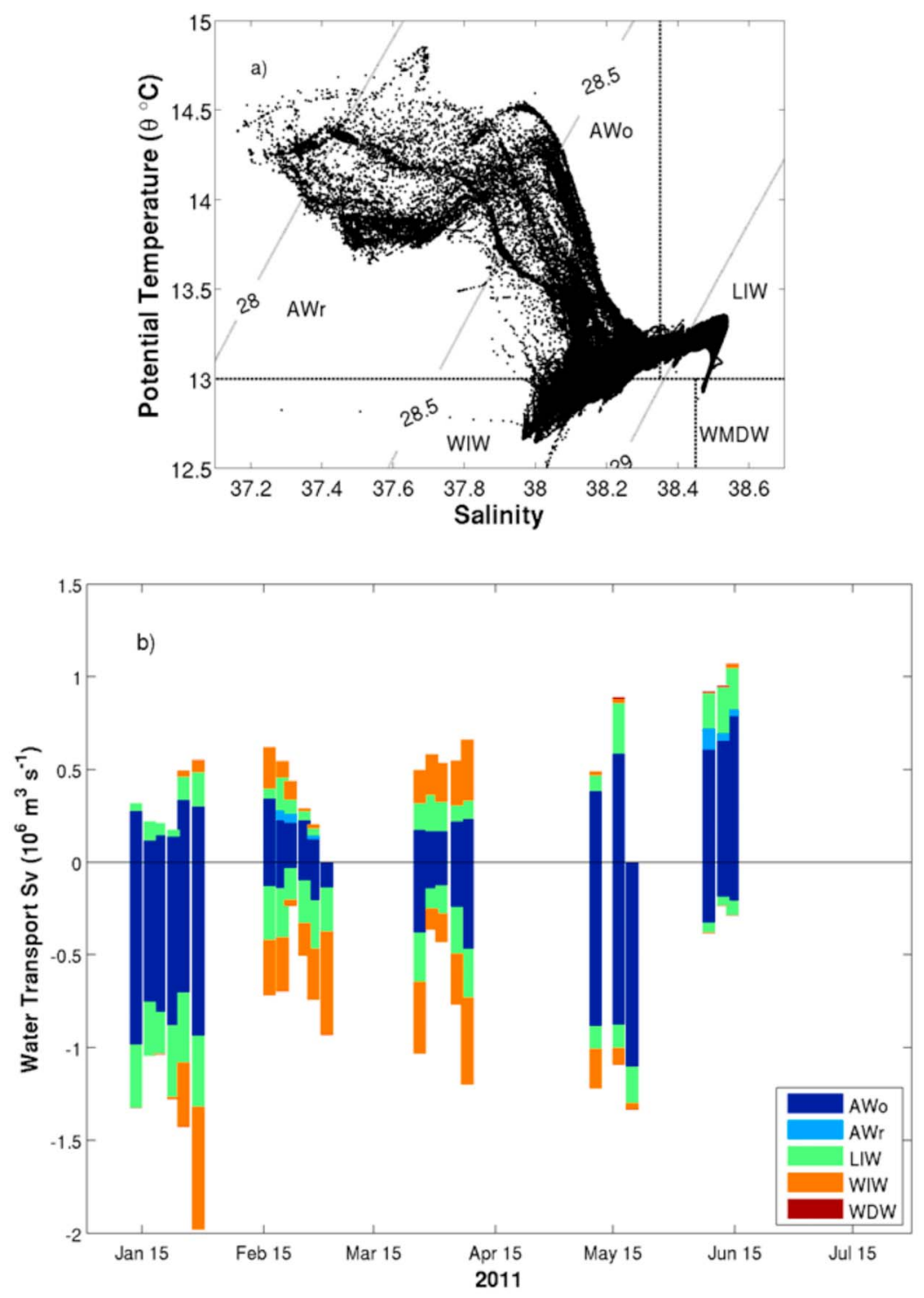

Figure 2. (a) $\theta / \mathrm{S}$ diagram for the canalesFeb2011 mission to illustrate the different water masses present in the Ibiza Channel. The dotted lines represent potential density and the dashed lines separate the limits of the four main water masses, with an indication of the local separation of Atlantic Water into AW of longer residence (AWo) and AW of more recent Atlantic origin (AWr). (b) Transports flowing north (positive) and south (negative) through the Ibiza Channel per glider transect. Each bar represents the water transports for a single (2-day) glider transect of the deep (central) part of the channel by water mass, the total bar height represents the total volume of water transported.

[9] Data from the glider mounted unpumped CTD (Seabird Electronics Inc.) was processed following standard oceanographic techniques adapted to glider data, including a salinity correction procedure to correct for thermal lag effects [see Garau et al., 2011]. The temperature and corrected salinity data from each dive/ascent were assumed to represent a vertical profile, mapped to the glider transect and interpolated (kriging) to a $1 \mathrm{~km}$ spacing. Potential temperature $(\theta)$ and corrected salinity (S) profiles were used to calculate geostrophic velocity perpendicular to the glider transect using the thermal wind equation, with an assumed zero velocity reference depth of $800 \mathrm{~m}$ or the seafloor where profile depth was shallower than $800 \mathrm{~m}$, following the method of Pinot et al. [1995]. Eight hundred meters was chosen as the reference level of zero velocity as all transects contained profiles of $800 \mathrm{~m}$ and sensitivity tests indicated that the use of a deeper reference level did not greatly influence the transports; $\pm 3 \%$ on average for a reference depth of $900 \mathrm{~m}$. This assumption is discussed further in Section 4. The geostrophic velocity perpendicular to the transect line was inferred from the dynamic height profiles and the profiles were then trimmed to the depth of the channel using a standard bathymetry product, SRTM30Plus [Becker et al., 2009]. The geostrophic water volume transports perpendicular to the glider transect were calculated from the geostrophic velocity (10 $\mathrm{m}$ bin averages) multiplied by the distance between interpolated profiles $(1 \mathrm{~km})$. For the transport by water mass calculation, regionally accepted values of $\theta$ and S [Pinot et al., 2002; Pinot and Ganachaud, 1999; López-Jurado et al., 2008] were used to identify the different water masses present in the Ibiza Channel (Figure 2a). 

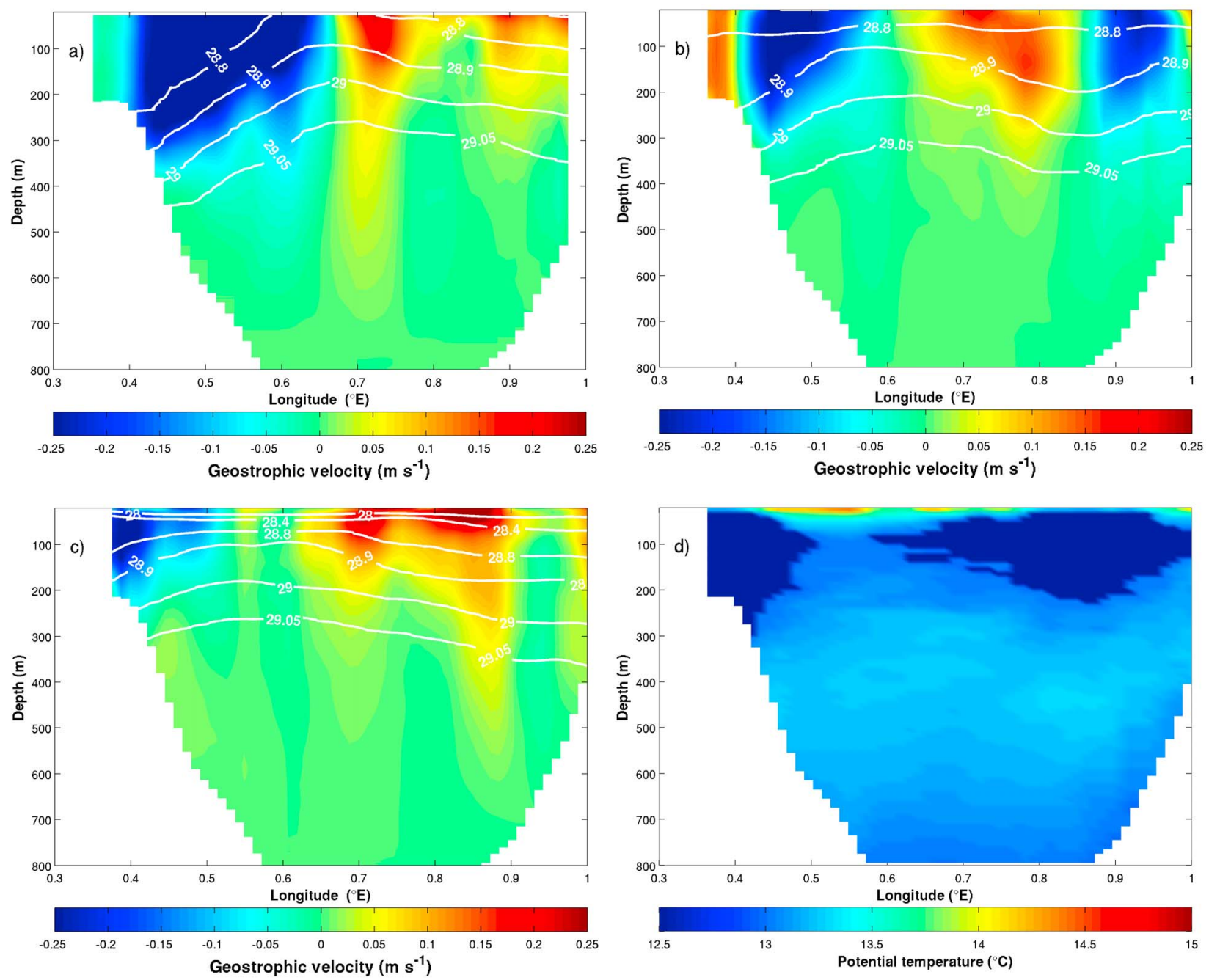

Figure 3. Cross channel sections of geostrophic velocity to illustrate the 'transport modes', with $\sigma_{t}$ isopycnals overlain in white. (a) 'NC dominant' mode 28 - 30/01/2011, (b) 're-circulatory' mode $06-08 / 04 / 2011$, and (c) 'inflow dominant' mode $07-09 / 06 / 2011$. (d) A cross section of potential temperature $(\theta)$ for the same transect as shown in b), with WIW (marked in dark blue) visibly associated with the eddy structures seen in the geostrophic velocity.

[10] Additional datasets analysed for the same period include; Level 3 daily Sea Surface Temperature (SST) data from GHRSST (Group for High Resolution SST), in-situ data from 4 oceanographic buoys (operated by Puertos del Estado, Spain and MétéoFrance, France), smoothed using a 24-hour low-pass band filter, contemporaneous ship-based CTD transects of the Ibiza Channel from the IEO RADMED Project (Instituto Español de Oceanografia: 'series temporales de datos oceanográficos en el Mediterráneo'), $8 \mathrm{~km}$ to the south of the glider transect, and $\theta, \mathrm{S}$ and absolute velocity ( $\mathrm{u}$ and $\mathrm{v}$ ) from a regional configuration of the Regional Ocean Modeling System (ROMS) model [Shchepetkin and McWilliams, 2003, 2005], implemented over the Balearic Sea and developed within the framework of the BALearic OPerational (BALOP) forecasting system [Tintoré et al., 2012].

\section{Results}

[11] The water transports calculated from the new glider monitoring in the Ibiza Channel are of a similar order to the previous seasonal studies (Table 1), however, for the first time we are able to see high frequency variability in these transports overlying the general trend of the partial seasonal cycle (Figure $2 b$ ). For example at the end of January the volume of water transported southward increases by $0.9 \mathrm{~Sv}$ over 6 days ( 2 transects), a change equivalent to the range of the previously defined seasonal cycle [Pinot et al., 2002]. Within this a $0.5 \mathrm{~Sv}$ increase was observed over 2 days, associated with the appearance of WIW in the channel. In March the reverse occurs as the total volume of water transported south decreases by approximately $0.7 \mathrm{~Sv}(65 \%)$ over 2 days, and between missions in February and May changes of the order of $1 \mathrm{~Sv}$ in both positive (northward) and negative (southward) transports occurred.

[12] The glider data also indicates patterns or 'modes' in the Ibiza Channel geostrophic transports that could simplify the previously observed complex pattern of flows [Pinot et al., 2002; Pinot and Ganachaud, 1999; Pinot et al., 1995]. Three 'modes' are proposed, for January and May a 'NC dominant' mode, characterized by a strong $\mathrm{NC}$ to $400 \mathrm{~m}$ depth with geostrophic velocities of the order of $0.2-0.4 \mathrm{~m} \mathrm{~s}^{-1}$ and a southward water volume transport of 1.2 to $2 \mathrm{~Sv}$. An example of this mode can be seen in see Figure 3a, where a channel section of geostrophic velocity from $28-30 / 01 / 2011$ 
shows a strong NC (negative velocity in the west of the channel). A 're-circulatory' mode is suggested for March and April, when the transports south are reduced and the surface and intermediate layers re-circulated by eddies. This can be seen in a more even distribution of the water volumes transported north and south (Figure 2b) and the transects of geostrophic velocity indicate the presence of eddies as paired north-south velocity structures (Figure $3 \mathrm{~b}$, at $0.40^{\circ} \mathrm{E}$ and at $0.45^{\circ} \mathrm{E}$ ), associated with dips in the $\sigma_{\mathrm{t}}=28.9$ isopycnals of order $100 \mathrm{~m}$ and lenses of WIW (Figure 3d). In June the transport pattern changes to an 'inflow dominant' mode, with northward transports of warmer less saline surface waters into the Balearic Basin (Figure 3c), these inflows are of order $1 \mathrm{~Sv}$ and the net flow is reversed.

[13] Data from oceanographic buoys located along the continental slope to the north of the Ibiza Channel (Figure 1) show a strong winter cooling event initiating on 18/01/2011, during which the air temperature at $2 \mathrm{~m}$ fell by $8-10^{\circ} \mathrm{C}$, the temperature at the sea surface also fell and increased wind velocities were recorded (Figures S2a-S2c, auxiliary material). Assuming WIW was produced during this cold event and was then advected south with the NC to the Ibiza Channel, arriving in late January (Figure 2b), using an estimated NC velocity of $0.3-0.4 \mathrm{~m} \mathrm{~s}^{-1}$ the formation of this WIW could be placed approximately $150 \mathrm{~km}$ to the north, coincident with the Ebro Delta region. This suggestion is supported by the more dramatic fall in temperature recorded by the 'Tarragona' buoy located to the northeast of the Ebro Delta (Figure S2c, auxiliary material) and in addition contemporaneous SST images indicate temperatures $<12.9^{\circ} \mathrm{C}$ across the Balearic Basin and later flowing through the Ibiza Channel (Figure S3, auxiliary material). Although WIW could have formed in the Gulf of Lion and migrated south over several weeks, the combination of glider, oceanographic buoy and satellite SST datasets, suggests that in the winter of 2011 WIW was produced locally in the Balearic Basin, as proposed by Salat and Font [1987] and more recently VargasYáñez et al. [2012].

\section{Discussion}

[14] For this analysis the glider sampling of the Ibiza Channel is assumed to be synoptic, however it could be argued that some of the observed variability is induced by a smearing of signals from high frequency dynamic structures, such as internal waves, due to the relatively slow speed of the glider in the horizontal $\left(25 \mathrm{~cm} \mathrm{~s}^{-1}\right)$. A recent study suggested that for depth dependent variables, such as geostrophic velocity, glider data is accurate for wave lengths $>30 \mathrm{~km}$ [Rudnick and Cole, 2011]. Comparing the ends of transects sampled closer in time, i.e. where the glider makes a turn (Table S2), indicated that there was not a consistent pattern of reduced change in properties on depth or density surfaces, between transect ends sampled closer in time. This suggests that the observed high frequency variability is largely dictated by changes in the dynamics of the Ibiza Channel, over periods of days, which is adequately captured by the glider. A comparison between glider data and ship-based sections from the IEO RADMED Project, with a lower resolution but slightly more synoptic (1 day) view, indicate that the structures observed by the glider are coherent with those observed by ship (not shown).
[15] The geostrophic transports calculated for the deep (central) part of the Ibiza Channel are taken to be representative of the 'total' geostrophic transports for the channel, however shelf transports could also play a role. To analyze the impact of this assumption a study was conducted comparing the pattern of transports in simulated glider transects sampled from the ROMS numerical simulation using the Balop forecasting system [Tintoré et al., 2012]. The results indicate that the glider observed structures in the deep channel capture $96-100 \%$ of the transports south and $93-$ $94 \%$ of the transports north. This makes sense; in earlier studies and in the glider data the NC is located at the edge of the shelf break on the western side of the Ibiza Channel (Figure 3a), whereas in the east the shelf area frequently has the same potential temperature $(\theta)$ and salinity $(\mathrm{S})$ as the deep channel (not shown) indicating that the transport is more important for the shallower AW inflows. A margin of error could be applied to the north and southward transports $(6 \%$ and $2 \%$ respectively) when comparing with previous studies that closed the section using box models [Pinot et al., 2002; Pinot and Ganachaud, 1999].

[16] When at the surface gliders calculate the difference between their actual and 'dead reckoned' position in order to adjust their flight path to account for the effect of ambient currents during their trajectory, this also provides a measure of absolute depth averaged velocity (absolute DAV) that could be used to determine absolute velocity at depth. The glider DAV is however dependent on the accuracy of the onboard compass, which due to its proximity to battery packs and other internal components requires a mission specific error calibration procedure [Merckelbach et al., 2008]. An analysis was undertaken to compare glider DAV with geostrophic DAV that showed that the difference between the glider and geostrophic DAV in the central channel was small, indicating that the assumption of zero velocity at $800 \mathrm{~m}$ (or the seafloor) was acceptable and within the error range for the DAV calculation. In addition, at the eastern end of the transect, a pattern indicative of compass error was visible on alternate transects in the glider DAV and therefore, as the compass error calibration procedure was not performed for the 2011 'canales' missions, the glider DAV was not used. With a reference level of zero velocity at $800 \mathrm{~m}$ some intermittent deep water flows, as noted in Pinot et al. [2002], are not captured, however the transports of Western Mediterranean Deep Water (WMDW) are estimated as low in the vicinity of the Ibiza Channel $(0.02 \mathrm{~Sv})$ [Pinot and Ganachaud, 1999] and therefore would not be expected to greatly influence the variability discussed here. The scale of variability in water transports captured by gliders provides a unique days-weeks view of the inter-basin exchange through the Ibiza Channel.

\section{Conclusions}

[17] Gliders enable us to see high frequency, days to weeks, variability in the inter-basin exchange of water masses that are on a par with the seasonal cycle. Although previous surveys noted high cruise-to-cruise variability, driven by mesoscale features and the large-scale seasonal cycle, they were insufficient to show that in fact water volumes exchanged through the Ibiza Channel fluctuate on 'weather' timescales. Potential 'modes' of water mass transports are also visible, simplifying a previously complex pattern. The glider data, in combination with oceanic buoys and satellite 
SST, supports the suggestion that WIW can form in the Ebro Delta area of the Balearic sub-basin and also clearly confirms the influential role that WIW plays in winter/spring flows in the Ibiza Channel, contributing to the interplay between basin and mesoscale variability. This is an observation that has significant implications for regional models that do not replicate well, if at all, the production of this winter produced water mass.

[18] The impact of variability at a variety of scales, seasonal to sub-seasonal, is becoming increasingly important in identifying the signature of both natural climatic oscillations and the long-term trends brought about by human-induced changes in atmospheric composition [Mote et al., 2011]. High frequency variability in basin scale circulation systems is increasingly being observed [Cunningham et al., 2007; Meinen et al., 2010], however physical processes still need to be defined at many key points in the ocean system at scales of days-weeks in order to better understand the oceans variability and constrain modelling of physical and biogeochemical processes [Sun and Frank, 2010]. The arrival of autonomous underwater gliders provides a technological key to unlocking sub-seasonal variability at many critical 'choke' points, in a cost effective manner.

[19] Acknowledgments. This research was partially funded by the European Commission Projects, MyOcean, PERSEUS, and JERICO. The glider data collected under a monitoring program operated by ICTS SOCIB (Balearic Islands Coastal Ocean Observing and Forecast System) with inkind support from IMEDEA (CSIC-UIB). Ship-based CTD data provided by IEO. SST data from GRHSST made available by IFREMER (France) under the MyOcean Project. The buoy data provided by Puertos del Estado and Météo-France/CNRM under the Hymex Project. The SRTM30Plus data set can be downloaded from several sources, e.g., ftp://topex.ucsd.edu/pub/ srtm30 plus/srtm30/data/

[20] The editor thanks two anonymous reviewers for assistance evaluating this manuscript.

\section{References}

Alemany, F., L. Quintanilla, P. Velez-Belchí, A. García, D. Cortés, J. M. Rodríguez, M. L. Fernández de Puelles, C. González-Pola, and J.-L. López-Jurado (2010), Characterization of the spawning habitat of Atlantic bluefin tuna and related species in the Balearic Sea (western Mediterranean), Prog. Oceanogr., 86, 21-38, doi:10.1016/j.pocean.2010.04.014.

Baird, M. E., and K. R. Ridgway (2012), The southward transport of sub-mesoscale lenses of Bass Strait Water in the centre of anti-cyclonic mesoscale eddies, Geophys. Res. Lett., 39, L02603, doi:10.1029/ 2011 GL050643.

Becker, J. J., et al. (2009), Global bathymetry and elevation data at 30 arc seconds resolution: SRTM30_PLUS, Mar. Geod., 32(4), 355-371, doi:10.1080/01490410903297766.

Castelao, R., et al. (2008), Seasonal evolution of hydrographic fields in the central Middle Atlantic Bight from glider observations, Geophys. Res. Lett., 35, L03617, doi:10.1029/2007GL032335.

Castellon, A., J. Font, and E. Garcia (1990), The Liguro-Provençal-Catalan current (NW Mediterranean) observed by Doppler profiling in the Balearic Sea, Sci. Mar., 54(3), 269-276.

Conan, P., and C. Millot (1995), Variability of the northern current off Marseilles, western Mediterranean Sea, from February to June 1992, Oceanol. Acta, 18(2), 193-205.

Cunningham, S. A., et al. (2007), Circulation at $26.5^{\circ} \mathrm{N}$ temporal variability of the Atlantic meridional overturning circulation, Science, 317, 935-938, doi: $10.1126 /$ science. 1141304

Garau, B., et al. (2011), Thermal lag correction on Slocum CTD glider data, J. Atmos. Oceanic Technol., 28(9), 1065-1071, doi:10.1175/JTECH-D10-05030.1.

López-Jurado, J. L., and G. del Rio (1994), Dinàmica asociadad a las masas de agua en el canal de Ibiza en noviembre de 1990 y marzo de 1991, Bol. Inst. Esp. Oceanogr., 10(1), 3-22.

López-Jurado, J.-L., M. Marcos, and S. Monserrat (2008), Hydrographic conditions affecting two fishing grounds of Mallorca island (Western Mediterranean): During the IDEA Project (2003-2004), J. Mar. Syst., 71, 303-315, doi:10.1016/j.jmarsys.2007.03.007.
Martin, J. P., C. M. Lee, C. C. Eriksen, C. Ladd, and N. B. Kachel (2009), Glider observations of kinematics in a Gulf of Alaska eddy, J. Geophys. Res., 114, C12021, doi:10.1029/2008JC005231.

Meinen, C. S., M. O. Baringer, and R. F. Garcia (2010), Florida Current transport variability: An analysis of annual and longer-period signals, Deep Sea Res., Part I, 57, 835-846, doi:10.1016/j.dsr.2010.04.001.

Merckelbach, L. M., R. D. Briggs, D. A. Smeed, and G. Griffiths (2008). Current measurements from autonomous underwater gliders, in Proceedings of the IEEE/OES 9th Working Conference on Current Measurement Technology, pp. 61-67, Inst. Electr. Eng., Piscataway, N. J., doi:10.1109/ CCM.2008.4480845.

Meredith, M. P., et al. (2011), Sustained monitoring of the Southern Ocean at Drake Passage: Past achievements and future priorities, Rev. Geophys., 49, RG4005, doi:10.1029/2010RG000348.

Monserrat, S., J.-L. López-Jurado, and M. Marcos (2008), A mesoscale index to describe the regional circulation around the Balearic Islands, J. Mar. Syst., 71, 413-420, doi:10.1016/j.jmarsys.2006.11.012.

Mote, P., L. Brekke, P. Duffy, and E. Maurer (2011), Guidelines for conducting Climate Scenarios, Eos Trans. AGU, 92(31), 257, doi:10.1029/ $2011 \mathrm{EO} 310001$.

Pinot, J. M., and A. Ganachaud (1999), The role of winter intermediate waters in the spring-summer circulation of the Balearic Sea, 1. Hydrography and inverse box modeling, J. Geophys. Res., 104(C12), 29,843-29,864, doi:10.1029/1999JC900202.

Pinot, J. M., J. Tintoré, and D. Gomis (1995), Quasi-synoptic variability in the Balearic Sea, Deep Sea Res., Part I, 41(5/6), 897-914.

Pinot, J. M., J. L. López-Jurado, and M. Riera (2002), The CANALES experiment (1996-1998). Interannual, seasonal, and mesoscale variability of the circulation in the Balearic Channels, Prog. Oceanogr., 55, 335-370, doi:10.1016/S0079-6611(02)00139-8.

Rudnick, D. L., and S. T. Cole (2011), On sampling the ocean using underwater gliders, J. Geophys. Res., 116, C08010, doi:10.1029/2010JC006849.

Rudnick, D. L., R. E. Davis, C. C. Eriksen, D. M. Frantatoni, and M. J. Perry (2004), Underwater gliders for ocean research, Mar. Technol. Soc. J., 38(1), 38-59.

Ruiz, S., A. Pascual, B. Garau, I. Pujol, and J. Tintoré (2009), Vertical motion in the upper ocean from glider and altimetry data, Geophys. Res. Lett., 36, L14607, doi:10.1029/2009GL038569.

Ruiz, S., L. Renault, B. Garau, and J. Tintoré (2012), Underwater glider observations and modeling of an abrupt mixing event in the upper ocean, Geophys. Res. Lett., 39, L01603, doi:10.1029/2011GL050078.

Sabatés, A., M. P. Olivar, J. Salat, I. Palomera, and F. Alemany (2007), Physical and biological processes controlling the distribution of fish larvae in the NW Mediterranean, Prog. Oceanogr., 74, 355-376, doi:10.1016/j.pocean.2007.04.017.

Salat, J., and J. Font (1987), Water mass structure near and offshore the Catalan Coast during the winters of 1982 and 1983, Ann. Geophys., Ser. B, $5(1), 49-54$.

Send, U., et al. (2010), Towards an integrated observing system: In situ observations, in Proceedings of OceanObs '09: Sustained Ocean Observations and Information for Society, ESA Publ. WPP-306, vol. 1, pp. 35, Eur. Space Agency, Venice, Italy, doi: doi:10.5270/OceanObs09.pp.35.

Shchepetkin, A. F., and J. C. McWilliams (2003), A method for computing horizontal pressure-gradient force in an ocean model with a non-aligned vertical coordinate, J. Geophys. Res., 108(C3), 3090, doi:10.1029/ $2001 \mathrm{JC} 001047$.

Shchepetkin, A. F., and J. C. McWilliams (2005), The regional oceanic modeling system (ROMS): A split-explicit, free-surface, topographyfollowing-coordinate oceanic model, Ocean Modell., 9, 347-404, doi:10.1016/j.ocemod.2004.08.002.

Sun, D.-Z., and B. Frank (2010), Climate Dynamics: Why Does Climate Vary?, Geophys. Monogr. Ser., vol. 189, 216 pp., AGU, Washington, D. C., doi:10.1029/GM189.

Testor, P., et al. (2010), Gliders as a component of future observing systems, in Proceedings of the OceanObs'09: Sustained Ocean Observations and Information for Society, ESA Publ. WPP-306, vol. 1, edited by J. Hall, D. E. Harrison, and D. Stammer, pp. 89, Eur. Space Agency, Venice Italy, doi:10.5270/OceanObs09.cwp.89.

Tintoré, J., et al. (2012), SOCIB the impact of new marine infrastructures in understanding and forecasting the Mediterranean Sea, in Designing Med-SHIPS: A Program for Repeated Oceanographic Surveys, pp. 99-118, CIESM, Monaco.

Todd, R. E., D. L. Rudnick, M. R. Mazloff, R. E. Davis, and B. D. Cornuelle (2011), Poleward flows in the southern California Current System: Glider observations and numerical simulation, J. Geophys. Res., 116, C02026, doi:10.1029/2010JC006536.

Vargas-Yáñez, M., et al. (2012), Extreme Western Intermediate Water formation in winter 2010, J. Mar. Syst., doi:10.1016/j.jmarsys.2012.05.010, in press. 